\title{
PENGARUH AVERAGE TAX RATE, SIZE,GROWTH, FIXED ASSET RATIO, FINANCIAL LEVERAGE, DAN WORKING CAPITAL TERHADAP PROFITABILITY
}

\author{
ERIKA JIMENA ARILYN \\ BENY \\ FRANSISCA \\ Trisakti School of Management, Jl. Kyai Tapa no. 20 Jakarta, Indonesia \\ erika@stietrisakti.ac.id, beny@stietrisakti.ac.id
}

\begin{abstract}
The purpose of this research is to analyze empirically the influence of average tax rate, size, growth, fixed asset ratio, financial leverage, and working capital toward profitability. The object of this research is food and beverage companies that listed in Indonesia Stock Exchange period 2004-2014. The purposive sampling is used as sampling technique, in which only 6 companies meet the sampling criteria, resulting 66 data obsevations used in this research. Data were analyzed using Eviews8 panel data regression with fixed effect model to test the hyphotesis. The results shows that financial leverage and working capital have influence to profitability. In the other hand, average tax rate, size, growth, and fixed asset ratio have no influence to profitability. Overall, the independent variables influence financial leverage simultaneously.
\end{abstract}

Keywords: Profitability, average tax rate, size, growth, fixed asset ratio, financial leverage, working capital

Abstrak: Penelitian ini bertujuan untuk menganalisis secara empiris pengaruh dari average tax rate, size, growth, fixed asset ratio, financial leverage, dan working capital terhadap profitability. Objek penelitian ini adalah perusahaan makanan dan minuman yang terdaftar di Bursa Efek Indonesia periode 2004-2014. Metode pemilihan sampel yang digunakan adalah purposive sampling, dimana hanya 6 perusahaan yang memenuhi kriteria pemilihan sampel sehingga terdapat 66 data yang digunakan dalam penelitian ini. Data dianalisis menggunakan teknik regresi data panel, dengan model fixed effect untuk menguji hipotesis dan diuji menggunakan software Eviews 8. Hasil penelitian menunjukkan financial leverage dan working capital berpengaruh terhadap profitability, sedangkan average tax rate, size, growth, dan fixed asset ratio tidak berpengaruh terhadap profitability. Secara keseluruhan, variabel independen mempengaruhi profitability secara simultan.

Kata kunci: Profitability, average tax rate, size, growth, fixed asset ratio, financial leverage, working

\section{PENDAHULUAN}

Setiap perusahaan mempunyai
tujuan yang ingin dicapai, dan dalam
menjalankan operasinya perusahaan selalu
diarahkan untuk pencapaian tujuan yang
telah ditetapkan. Adapun tujuan didirikan perusahaan adalah memperoleh kas dalam jumlah besar dengan menekan biaya dan meningkatkan manfaat yang diperoleh. (Ross et al. 2013, 4).

Untuk mencapai tujuan yang telah ditetapkan, perusahaan membutuhkan manajer yang tepat untuk menjalankan 
fungsi-fungsi manajemen. Seorang manajer harus dapat merencanakan dan mengendalikan aktivitas-aktivitas perusahaan yang berkaitan erat dengan kelangsungan hidup perusahaan. Keberhasilan suatu perusahaan akan dilihat dari tingkat keuntungan maksimal yang dapat dihasilkan dalam jangka panjang, serta sangat tergantung dengan peran fungsi dan peran tugas seorang manajer keuangan (Tampubolon 2013, 4).

Laba (Profit) dapat ditingkatkan dengan meningkatkan investasi dalam aset yang menguntungkan, yang mampu menghasilkan tingkat laba yang tinggi. Semakin besar modal kerja bersih, perusahaan semakin tidak berisiko berarti perusahaan likuid (Sjahrial 2012, 119). Profitability (Profitabilitas) menunjukkan kemampuan perusahaan memperoleh laba dari aktivitas-aktivitas yang dilakukannya. Tingkat profitabilitas yang tinggi menggambarkan kondisi keuangan yang baik, perusahaan dinilai memiliki kinerja yang baik dan memiliki keunggulan dibandingkan perusahaan lain. Dengan profitabilitas yang tinggi perusahaan akan memiliki arus kas yang cukup untuk membiayai aktivitasaktivitas perusahaannya.

Peneliti terdahulu Al-Jafari dan Al Samman (2015) serta peneliti terdahulu selama beberapa tahun terakhir baik di negara maju maupun di negara berkembang telah mencoba untuk menganalisis faktorfaktor yang mempengaruhi profitability, namun masih terdapat perbedaan hasil penelitian. Kesenjangan inilah yang menimbulkan masalah untuk diteliti.

Penelitian ini dilakukan untuk mengetahui pengaruh average tax rate, size, growth, fixed asset ratio, financial leverage, dan working capital terhadap profitability.

\section{Pecking Order Theory}

Pecking Order Theory menjelaskan urutan dalam pemilihan sumber dana. Perusahaan cenderung mengutamakan pendanaan dari sumber internal guna pembayaran dividen, pendanaan investasi, dan pemenuhan kebutuhan operasional perusahaan. Perusahaan yang menghasilkan profit tinggi akan mengurangi pendanaan eksternalnya. Menurut Gitman dan Zutter (2012, 534), "Pecking order theory is a hierarchy of financing that begins with retained earnings, which is followed by debt financing and finally external equity financing. When managers want to finance a new project, they will first do so using retained earnings. If internally generated cash is insufficient to fund new investment, then managers will raise external financing through the debt markets. Issuing new equity is their last resort."

\section{Signalling Theory}

Signalling Theory merupakan langkahlangkah manajemen dari perusahaan yang sebenarnya memberikan petunjuk secara implisit kepada investor tentang bagaimana manajemen memandang prospek perusahaan. Asumsi dalam signalling theory ini adalah bahwa manajemen perusahaan mempunyai informasi yang lebih akurat tentang prospek perusahaan yang tidak diketahui oleh investor (asymmetric information). Saat perusahaan memiliki informasi mengenai prospek bisnis yang menguntungkan di masa depan, perusahaan akan mencari dana untuk membiayai peluang investasi tersebut, dimana selain menggunakan modal sendiri perusahaan juga akan menerbitkan hutang. Hal ini menandakan bahwa perusahaan memiliki keyakinan akan menghasilkan arus kas yang cukup di masa depan untuk menyelesaikan hutang. Perusahaan dalam kondisi buruk akan menggunakan pendanaan eksternal lain, berupa penerbitan saham, karena perusahaan merasa akan kesulitan melunasi kewajiban 
hutangnya dan memperbesar kemungkinan kebangkrutan.

\section{Return on Assets}

Menurut Gitman dan Zutter $(2012,81)$, "Return on total assets (ROA) is measures the overall effectiveness of management in generating profits with its available assets. The higher the firm's return on total assets, the company condition will be better." Menurut Sartono $(2000,130)$ ROA merupakan "Ukuran efektivitas perusahaan dalam menghasilkan keuntungan dengan memanfaatkan aktiva tetap yang digunakan untuk operasi." Keown et al. $(2005,77)$ menyatakan bahwa "return on assets determines the amount of net income produced on a firm's assets by relating net income to total assets." Maka dapat disimpulkan bahwa return on asset (ROA) adalah pengukuran kemampuan perusahaan secara keseluruhan untuk menghasilkan laba terhadap total asset perusahaan.

\section{Average Tax Rate}

Menurut Gitman (2012, 47), "average tax rate is a firm's taxes divided by its taxable income." Stroup et al. $(2006,98)$ menyatakan bahwa "average tax rate is tax liability divided by taxable income it is the percentage of income paid in taxes." Keown et al. $(2005,43)$ menyatakan bahwa "average tax rate is taxes owed by the firm divided by the firm's taxable income." Jadi dapat disimpulkan average tax rate merupakan tingkat pajak perusahaan atas beban pajaknya yang kemudian dibagi dengan penghasilan kena pajaknya.

\section{Size}

Keown et al. $(2005,508)$ menyatakan bahwa "Ukuran perusahaan adalah dapat dilihat dari asset, penjualan atau profit dari perusahaan itu sendiri." Menurut Riyanto (2002, 313) yang dimaksud dengan ukuran perusahaan adalah besar kecilnya perusahaan dilihat dari besarnya nilai equity, nilai penjualan, atau nilai total aktiva. Reilly and
Brown $(2006,179)$ menyatakan "Size refers to how large or small a firm is measures by firm's market value." Jadi dapat disimpulkan bahwa size merupakan besar kecilnya perusahaan dilihat dari asset dan penjualan perusahaan.

\section{Growth}

Menurut Brigham dan Ehrhardt (2010, 449), "Pertumbuhan penjualan adalah perubahan penjualan selama periode fluktuasi tertentu setiap tahun." Menurut Brealey et al. $(2006,801)$, "Firm's growth is the percentage of change in the company's net value of total sales." Menurut Brigham dan Houston (2010, $100)$, "Sales growth must be balanced against the cost of achieving that growth." Jadi dapat disimpulkan bahwa growth adalah persentase perubahan penjualan perusahaan selama periode tertentu setiap tahun.

\section{Fixed Asset Ratio}

Menurut Sartono (2000, 126), Fixed asset ratio memperlihatkan sejauh mana efektivitas perusahaan menggunakan aktiva tetapnya seperti gedung, kendaraan, dan mesin. Menurut Sundjaja dan Barlian (2003, 138), "Fixed asset ratio merupakan rasio yang digunakan untuk mengukur keseluruhan asset yang dimiliki perusahaan yang mempunyai nilai material yang tinggi sebagai jaminan kekayaan perusahaan." Menurut Hanafi dan Halim (2009, 80), "Fixed asset ratio merupakan rasio yang digunakan untuk mengukur sejauh mana perusahaan dapat menghasilkan aktiva tetap sebagai kekayaan yang dimiliki perusahaan." Jadi dapat disimpulkan bahwa fixed asset ratio adalah perbandingan antara aktiva tetap dengan total aktiva yang digunakan untuk mengukur efektivitas perusahaan dalam menggunakan aktiva tetapnya.

\section{Financial Leverage}

Menurut Gitman dan Zutter $(2012,76)$, "Financial leverage is the magnification of risk and return through the use of fixed-cost financing, such as debt and preferred stock." 
Ross et al. $(2013,24)$ menyebutkan, "The use of debt in a firm's capital structure is called financial leverage." Menurut Sutrisno (2009, 230), "Financial leverage terjadi akibat perusahaan menggunakan sumber dana dari hutang yang menyebabkan perusahaan harus menanggung beban tetap, atas penggunaan dana perusahaan tersebut setiap tahunnya maka dibebani biaya bunga." Jadi dapat disimpulkan bahwa financial leverage adalah penggunaan aset atau hutang yang membawa konsekuensi beban tetap, berupa biaya bunga.

\section{Working Capital}

Menurut Keown, et al $(2005,646)$ Working capital merupakan "The firm's total investment in current assets or assets that it expects to be converted into cash within a year or less." Menurut Gitman dan Zutter (2012, 601), "Current assets, commonly called working capital, represent the portion of investment that circulates from one form to another in the ordinary conduct of business." Menurut Weston et al. $(1996,332)$ Working capital merupakan "A firm's investment in shortterm assets." Jadi dapat disimpulkan bahwa working capital adalah investasi perusahaan terhadap aset lancar atau aset yang dapat dikonversi menjadi kas dalam waktu satu tahun atau kurang.

\section{METODE PENELITIAN}

Obyek dalam penelitian ini adalah perusahaan makanan dan minuman yang terdaftar di Bursa Efek Indonesia periode 20042014. Teknik pengambilan sampel dalam penelitian ini menggunakan metode purposive sampling. Purposive sampling adalah teknik penentuan sampel dengan pertimbangan tertentu (Sugiyono 2010, 122). Kriteria-kriteria pemilihan sampel yang digunakan dalam penelitian ini adalah perusahaan makanan dan minuman yang terdaftar dalam Bursa Efek Indonesia periode 2004-2014 dan menerbitkan laporan keuangan yang berakhir pada tanggal 31 Desember 2004-2014 dengan penyajian dalam rupiah.

Variabel dependen dalam penelitian ini adalah profitability. Variabel profitability dalam penelitian ini diproksikan dengan Return on Assets. Return on Assets (ROA) adalah pengukuran kemampuan perusahaan secara keseluruhan untuk menghasilkan laba terhadap total aset perusahaan. Dalam Al-Jafari dan Al Samman $(2015,306)$, return on assets (ROA) dapat dihitung dengan:

Average tax rate adalah tingkat pajak perusahaan atas beban pajaknya yang kemudian dibagi dengan penghasilan kena pajaknya. Menurut Al-Jafari dan Al Samman $(2015,306)$. Size adalah ukuran besar kecilnya perusahaan dilihat dari penjualan yang dimiliki perusahaan. Menurut Al-Jafari dan Al Samman $(2015,306)$, size dapat dihitung dengan Size : Natural logarithm of sales. Growth adalah persentase perubahan jumlah penjualan perusahaan selama periode tertentu. Menurut Nunes, Serrasqueiro, dan Sequeira (2009, 697). Fixed Asset Ratio adalah perbandingan antara aktiva tetap dengan total aktiva perusahaan yang dapat menentukan besarnya efektivitas perusahaan menggunakan aktiva tetapnya. Menurut Al-Jafari dan Al Samman $(2015,306)$. Financial Leverage adalah penggunaan aset atau hutang yang membawa konsekuensi beban tetap, berupa biaya bunga. Menurut Nunes, Serrasqueiro, dan Sequeira $(2009,697)$. Working capital adalah investasi perusahaan terhadap aset lancar atau aset yang dapat dikonversi menjadi kas dalam waktu satu tahun atau kurang. MenurutAl-Jafari dan AI Samman $(2015,306)$.

\section{HASIL PENELITIAN}

Obyek penelitian yang digunakan dalam penelitian ini adalah perusahaan makanan dan minuman yang terdaftar di Bursa Efek Indonesia periode 2004-2014. Berdasarkan beberapa kriteria 
sampel, maka jumlah perusahaan yang digunakan dalam penelitian ini adalah sebanyak 6 perusahaan.

Tabel 1 Statistik Deskriptif

\begin{tabular}{lccccccc}
\hline Variabel & ROA & TAX & SIZE & GROWTH & FA & FL & WC \\
\hline Mean & 0.121010 & 0.151392 & 27.39604 & 0.247236 & 0.385112 & 0.528553 & 2.301531 \\
Median & 0.061391 & 0.270107 & 27.37719 & 0.178980 & 0.408344 & 0.471057 & 1.674013 \\
Maximum & 0.940222 & 1.929060 & 28.99629 & 1.998199 & 0.632632 & 4.366375 & 7.350685 \\
Minimum & -0.379278 & -3.864449 & 25.64873 & -0.398762 & 0.107353 & 0.162613 & 0.249470 \\
Std. Dev. & 0.180484 & 0.714233 & 0.815714 & 0.408714 & 0.146725 & 0.523587 & 1.638937 \\
\hline
\end{tabular}

Nilai statistik Chi-square adalah sebesar 33.842176 dan degree of freedom (df) sebesar 5 adalah 11.07050. Dengan demikian, dapat disimpulkan bahwa model penelitian yang digunakan dalam penelitian ini adalah model fixed effect. Hasil serupa juga dapat dilihat dari nilai probabilitasnya, dimana nilai probabilitas lebih kecil dari a $(0.0000<0.05)$.

Tabel 2 Hasil Uji Jarque-Bera

\begin{tabular}{cc}
\hline Skewness & 0.427937 \\
Kurtosis & 3.427285 \\
Jarque-Bera & 2.516503 \\
Probability & 0.284150 \\
\hline
\end{tabular}

Tabel di atas menunjukkan bahwa nilai skewness (0.427937) mendekati 0 dan nilai kurtosis (3.427285) mendekati 3. Nilai koefisien JarqueBera 2.516503 lebih kecil dari nilai distribusi Chi-
Square a $5 \%$ df(2) 5.99. Nilai probabilitasnya, probabilitas Jarque-Bera 0.284150 lebih besar dari a $5 \%$, sehingga dapat disimpulkan bahwa data tersebut berdistribusi normal.

Tabel 3 Hasil Uji Multikolinearitas

\begin{tabular}{cccrrrr}
\hline & TAX & SIZE & GROWTH & FA & FL & WC \\
\hline TAX & 1.000000 & 0.201101 & -0.196399 & -0.167496 & -0.109006 & 0.032555 \\
SIZE & 0.201101 & 1.000000 & 0.111292 & 0.017425 & -0.267660 & -0.082552 \\
GROWTH & -0.196399 & 0.111292 & 1.000000 & -0.023305 & 0.063804 & -0.000174 \\
FA & -0.167496 & 0.017425 & -0.023305 & 1.000000 & 0.074019 & -0.498378 \\
FL & -0.109006 & -0.267660 & 0.063804 & 0.074019 & 1.000000 & -0.341883 \\
WC & 0.032555 & -0.082552 & -0.000174 & -0.498378 & -0.341883 & 1.000000 \\
\hline
\end{tabular}

Berdasarkan tabel 3, penelitian ini tidak terdapat multikolinearitas karena korelasi antar variabel independen yang dimasukkan dalam penelitian kurang dari 0.89 . Nilai probabilitas ChiSquare (0.1198) > alpha 0.05, maka dapat disimpulkan bahwa dalam model regresi tidak 
terjadi masalah heteroskedastisitas. Nilai DurbinWatson adalah sebesar 1.840320. Dengan $k=6$ dan $\mathrm{n}=66$, maka diperoleh nilai $\mathrm{dL}=1.4102$ dan nilai $\mathrm{dU}=1.8041$. Kesimpulan dari uji DurbinWatson dapat digambarkan sebagai berikut:

Tabel 4 Hasil Uji t

\begin{tabular}{ccc}
\hline Variabel & t-statistics & Prob \\
\hline TAX & 1.031498 & 0.3065 \\
SIZE & 1.628470 & 0.1088 \\
GROWTH & 1.064156 & 0.2916 \\
FA & -1.713323 & 0.0919 \\
FL & -2.711418 & 0.0088 \\
WC & 2.024098 & 0.0475 \\
\hline Dependent Variable: ROA &
\end{tabular}

Hasil penelitian menunjukkan bahwa average tax rate memiliki probabilitas sebesar 0.3065 yang lebih besar dari nilai a $(0.3065>0.05)$. Hal ini menunjukkan bahwa tidak terdapat pengaruh average tax rate terhadap profitability.

Hasil penelitian menunjukkan bahwa size memiliki probabilitas sebesar sebesar 0.1088 yang lebih besar dari nilai a $(0.1088>0.05)$. Hal ini menunjukkan bahwa tidak terdapat pengaruh size terhadap profitability.

Hasil penelitian menunjukkan bahwa growth memiliki probabilitas sebesar 0.2916 yang lebih besar dari nilai a $(0.2916>0.05)$. Hal ini menunjukkan bahwa tidak terdapat pengaruh growth terhadap profitability.

Hasil penelitian menunjukkan bahwa fixed asset ratio memiliki probabilitas sebesar 0.0919 yang lebih besar dari nilai a $(0.0919>0.05)$. Hal ini menunjukkan bahwa tidak terdapat pengaruh fixed asset ratio terhadap profitability.

Hasil penelitian menunjukkan bahwa financial leverage memiliki probabilitas sebesar 0.0088 yang lebih kecil dari nilai a $(0.0088 \leq 0.05)$. Hal ini menunjukkan bahwa terdapat pengaruh financial leverage terhadap profitability.

Hasil penelitian menunjukkan bahwa working capital memiliki probabilitas sebesar 0.0475 yang lebih kecil dari nilai a $(0.0475 \leq 0.05)$. Hal ini menunjukkan bahwa terdapat pengaruh working capital terhadap profitability.

\section{PENUTUP}

Penelitian ini dilakukan untuk membuktikan secara empiris pengaruh average tax rate, size, growth, fixed asset ratio, financial leverage, dan working capital terhadap profitability pada perusahaan makanan dan minuman yang terdaftar di Bursa Efek Indonesia periode 20042014. Berdasarkan hasil analisis dan pembahasan, maka kesimpulan yang dapat diambil adalah sebagai berikut: Tidak terdapat pengaruh average tax rate terhadap profitability, hasil penelitian ini berbeda dengan penelitian yang dilakukan oleh Al-Jafari dan Al Samman (2015). Tidak terdapat pengaruh size terhadap profitability, hasil penelitian ini berbeda dengan penelitian yang dilakukan oleh Al-Jafari dan Al Samman (2015) dan Nunes, Serrasqueiro, dan Sequeira (2009). Tidak terdapat pengaruh growth terhadap profitability, hasil penelitian ini berbeda dengan penelitian yang dilakukan oleh Al-Jafari dan Al Samman (2015) dan Nunes, Serrasqueiro, dan Sequeira (2009). Tidak terdapat pengaruh fixed asset ratio terhadap profitability, hasil penelitian ini berbeda dengan penelitian yang dilakukan oleh AlJafari dan Al Samman (2015) dan Burja (2011). Terdapat pengaruh financial leverage terhadap, hasil penelitian ini konsisten dengan penelitian yang dilakukan oleh Al-Jafari dan Al Samman (2015) dan Nunes, Serrasqueiro, dan Sequeira 
(2009). Terdapat pengaruh working capital terhadap profitability, hasil penelitian ini konsisten dengan hasil penelitian yang dilakukan oleh AlJafari dan Al Samman (2015) serta Saleem dan Rehman (2011), dimana dalam penelitian tersebut variabel working capital berpengaruh terhadap profitability.

Masih terdapat beberapa keterbatasan dalam penelitian ini, yang antara lain: Penelitian ini hanya menggunakan perusahaan makanan dan minuman sebagai obyek penelitian sehingga sampel yang dihasilkan dan digunakan dalam penelitian ini sedikit, hanya menggunakan periode penelitian 11 tahun, dan ada banyak variabel yang mempengaruhi profitability, tetapi dalam penelitian ini hanya menggunakan 6 variabel independen. Berdasarkan keterbatasan tersebut maka peneliti menyarankan beberapa rekomendasi yang dapat digunakan dalam penelitian selanjutnya, yaitu: penelitian selanjutnya dapat menggunakan sektor aneka industri sebagai obyek penelitian, dapat menggunakan periode penelitian lebih dari 11 tahun, dan dapat meneliti variabel-variabel independen lain selain variabel yang digunakan dalam penelitian ini yang mungkin berpengaruh terhadap profitability.

\section{REFERENCES:}

Al-Jafari, Mohamed Khaled, and Al Samman, Hazem. 2015. Determinants of Profitability: Evidence from Industrial Companies Listed on Muscat Securities Market. Review of European Studies; Vol. 7, 303-311.

Brealey, Richard A. and Myers, Stewart C. 2006. Principles of Corporate Finance (International Edition). New York: Mc. Graw-Hill Companies, Inc.

Brigham, Eugene F. and Michael C. Ehrhardt. 2010. Financial Management, 13th edition. USA: South Western. Brigham, Eugene F. and Houston, Joel F. 2010. Dasar-Dasar Manajemen Keuangan. Jakarta: Salemba Empat.

Burja, Camelia. 2011. Factors Influencing the Company's Profitability. Annales Universitatis Apulensis Series Oeconomica; 13(2), 215-224.

Copeland, Tom, J. Fred Weston, dan Kuldeep Shastri. 2005. Financial Theory and Corporate Policy. 4th edition. USA: Pearson Education, Inc.

Gitman, Lawrence J., and Chad J. Zutter. 2012. Principles of Managerial Finance. 13th edition. United States of America: Pearson Education Limited.

Hanafi, Mamduh M., dan Abdul Halim. 2009. Analisis Laporan Keuangan. Yogyakarta: UPP STIM YKPN.

Kasmir. 2009. Analisis Laporan Keuangan. Jakarta: PT. Raja Grafindo Persada.

Keown, Arthur J., John D. Martin, J. William Petty, dan David F. Scott. 2005. Financial Management, 10th edition. International Edition.

Keown, Arthur J., John D. Martin, dan Sheridan J Titman. 2014. Financial Management: Principles and Applications. 12th edition. UK: Pearson Education Limited.

Nunes, P. J. M., Serrasqueiro, Z. M., and Sequeira, T. N. 2009. Profitability in Portuguese Service Industries: A panel data approach. The Service Industries Journal, 29(5), 693-707.

Pratheepan, T. 2014. A Panel Data Analysis of Profitability Determinants: Empirical Results from Sri Lankan Manufacturing Companies. International Journal of Economics, Commerce and Management, 2(12), 1-9.

Reilly, F., and K. C. Brown. 2006. Investment Analysis and Portfolio Management. 8th edition. Australia: Thomson South-Western.

Riyanto, B. 2002. Dasar-Dasar Pembelanjaan Perusahaan. Edisi Keempat. Yogyakarta: BPFE.

Ross, Stephen A., Randolph W. Westerfield, and Bradford D. Jordan. 2013. Fundamentals of Corporate Finance. 10th edition. McGraw-Hill.

Saleem, Qasim, and Rehman, Ramiz Ur. 2011. Impacts of Liquidity Ratios on Profitability (Case of Oil and Gas Companies of Pakistan). Interdisciplinary Journal of Research in Business; Vol. 1, Issue. 7, 95-98.

Sartono, Agus. 2000. Manajemen Keuangan, Teori dan Aplikasi. Edisi Kedua. Yogyakarta: BPFE UGM. 
Sjahrial, Dermawan. 2012. Pengantar Manajemen Keuangan. Edisi Keempat. Jakarta: Penerbit Mitra Wacana Media. 